\title{
Yoğun Bakım Hemşirelerinin Ötanazi, Ölüm ve Ölümcül Hastaya Karşı Tutumları*
}

\author{
The Attitudes of Intensive Care Nurses Towards Euthanasia, Death and Terminal Patients \\ Rana Cani, Hatice Tambağii, Melike Öztürkiii, Metin Kaykunoğluiv, Rabiye Erenoğluv, Fatma Gümüşoğluvi
}

iDr. Öğr. Üyesi, Akdeniz Üniversitesi Tıp Fakültesi, Tıp Tarihi ve Etik Anabilim Dalı, https://orcid.org/0000-0003-0655-4736

iiDoç Dr., Mustafa Kemal Üniversitesi Sağlık Bilimleri Fakültesi, Hemşirelik Bölümü, https://orcid.org/0000-0002-0812-2489

iiiDr. Öğr. Üyesi, Çukurova Üniversitesi Sağlık Bilimleri Fakültesi, Ebelik Bölümü, https://orcid.org/0000-0001-9452-4873

ivBilim Uzmanı, Mustafa Kemal Üniversitesi Sağlık Uygulama ve Araştırma Hastanesi, Dahiliye Yoğun Bakım,

https://orcid.org/0000-0003-3770-9198

vDr. Öğr. Üyesi, Mustafa Kemal Üniversitesi Sağlık Bilimleri Fakültesi, Hemşirelik Bölümü, https://orcid.org/0000-0003-3649-9336

viBilim Uzmanı, Hatay Devlet Hastanesi, Kulak Burun Boğaz-Çocuk Cerrahi Kliniği,https://orcid.org/0000-0001-8071-8845 Öz

Giriş: Hemşireler hastane ortamında yaşanılan ölümlere en yakın tanıklık eden sağlık profesyonellerindendir. Özellikle yoğun bakım hemşireleri bu durumla daha çok karşı karşıya kalmaktadırlar.

Amaç: Bu çalışmanın amacı da üniversite hastanesinin yoğun bakım ünitesinde görev alan hemşirelerin ötanazi, ölüm, ölümcül hastaya yaklaşım konusundaki tutumlarını belirlemektir.

Gereç ve Yöntem: Araştırmanın veri toplama formu iki kısımdan oluşmaktadır. Birinci kısımda 16 soruluk kişisel bilgi formu; ikinci kısımda Ötanazi, Ölüm ve Ölümcül Hastaya İlişkin Tutum Ölçeği (ÖTÖ) kullanılmıştır. Veriler Haziran -Aralık 2015 tarihleri arasında toplanmıştır. Araştırma evreni 367 yoğun bakım hemşiresinden oluşmakta olup araştırmaya katılmayı kabul eden ve ulaşılan 243 hemşireyle çalışma yürütülmüştür. Verilerin değerlendirilmesinde frekans dağılımı, Independent Sample t Test, One-Way Anova testi, Tukey testi kullanılmıştır. Araştırma için Mustafa Kemal Üniversitesi Klinik Araştırmalar Etik Kurul'undan izin alınmıştır.

Bulgular: Katılımcıların yaş ortalaması 26,71 , çalışma yılı ortalaması 5,84'dir. ÖTÖ puan ortalaması 85,07 'dir. Ölçeğin üç alt boyutundaki puan ortalamaları ise ötanaziye ilişkin tutum alt boyutu için 36,09; ölüme ilişkin tutum alt boyutu 25.57; ölümcül hastaya ilişkin tutum alt boyutu 23.40'dır.

Sonuç: Katılımcıların ölüm, ölümcül hasta ve ötanaziye yaklaşımlarının genel olarak olumsuz olduğunu göstermektedir. Katılımcıların ölümcül hastaya ilişkin tutumlarının ölçeğin diğer alt gruplarına göre daha olumlu olduğu görülmektedir.

Anahtar Kelime: Ötanazi, Ölüm, Yoğun bakım hemşiresi

\section{ABSTRACT}

Introduction: Nurses, being health professionals, are the closest witnesses of deaths occuring at hospital environment. Especially the intensive care unit nurses encounter this situation more than other health care workers.

Objective: Aims to study, to investigate the attitudes of intensive care nurses at two different university hospitals towards euthanasia, death and terminal patients.

Methods: The data collection form be formed 16 item personal information form and the Attitude Scale About Euthanasia, Death and Dying Patient (ASBEDDP). The data were collected between June -December 2015. The study's universe is composed of 367 nurses, 243 attainable intensive care unit nurses who accepted to attend the study has been included in the sample of the research. For data evaluation were used for, frequency distribution, Independent Sample t Test, One-Way Anova test and Tukey test. Ethics committee approval was received from Mustafa Kemal University Clinical Research Ethics Committee.

Results: The age average of participants was determined as 26,71 and average nurses working year was found to be 5.84 years. The average point for the Attitude Scale About Euthanasia, Death and Dying Patient was found as 85.07 points. The sub field scores were found as 36.09 for attitude towards euthanasia, 25.57 for attitude towards death and 23.40 for attitude towards terminal patient.

Conclusion: It was found that participants have a negative attitude towards death, dying patient and euthanasia in general. The attitude of participants towards dying patient was found to be more positive by comparison with other sub-fields of the scale.

Keywords: Euthanasia, Death, Intensive care nurse

*Lokman Hekim Dergisi, 2020; 10 (2): 190-200

DOI: $10.31020 /$ mutftd.693100

e-ISSN: 1309-8004

Geliş Tarihi - Received: 25 Şubat 2020; Kabul Tarihi - Accepted: 01 Nisan 2020

iletişim - Correspondence Author: Rana Can <ranacan@akdeniz.edu.tr> 


\section{Giriş ve Genel Bilgiler}

Ölüme dair konular tüm çağlarda insanları etkilemiş ve üzerinde konuşulmaya değer bir konu olmuştur. Hayatın bitişini ifade eden, yaşamı sınırlayan bir kavram olan ölüm, yaşam döngüsünün bir parçası olup var olmayı tehdit eder, mecburidir ve hayatı sınırlar. ${ }^{1}$ Ölümün kendisi kadar nerede ve ne şekilde gerçekleştiği; ona yüklediğimiz anlam ve ona karşı olan tutumumuz, ölüm ve ölüm hakkında söz söylememize yaşamımızı biçimlendirmemize yol açmaktadır.

Günümüzde ölümcül hastalığı olanlar hastaneye kaldırımakta ve ölümlerin büyük bir kısmı hastanelerde gerçekleşmektedir. ${ }^{2}$ Hemşireler hastane ortamında yaşanılan ölümlere en yakın tanıklık eden sağlık profesyonellerindendi. ${ }^{1}$ Özellikle yoğun bakım hemşireleri bu durumla daha çok karşı karşıya kalmaktadırlar. Yoğun bakımlarda görev yapan hemşireler yaşamın sonunda olan hastalara bakım vermede önemli role sahip olup ölümü yaklaşan hastaların bakımı hemşirelik mesleğinin en zor, en yıpratıcı yönlerinden biri olarak değerlendirilebilir. ${ }^{1,3}$ Yoğun bakımda çalışan hemşireler üzerinde yapılan çalışmalarda yoğun bakımda ölmek üzere olan hastalara karşı hemşirenin temel rollerinin konfor sağlamak, bakım vermek ve iyi bir dinleyici olmak olduğuna vurgu yapılmıştır. ${ }^{3,4}$

Çoğunlukla terminal dönemde dayanılmaz ağrı ve acıya katlanma, bu nedenle yaşam kalitesinde düşme bazı hastaların bu kadar kötü bir hayatı yaşamak yerine ölmeyi tercih etmesine/dilemesine neden olabilmektedir. ${ }^{5}$ Bazı hastalar da kendi yaşamlarını bir an evvel hızlıca sonlandırmak için hekim ya da hemşireden yardım isteyebilmektedir. Terminal dönem; hayati fonksiyonların belirli bir zaman dilimi içinde sonlanmasının beklendiği süreç olarak tanımlanırken terminal dönem hastası yaşamın sonuna gelmiş ölmek üzere olan hasta anlamı taşımaktadır ${ }^{1}$. Terminal dönem, ölüm kaygısının daha fazla yaşandığı, hemşire ve hasta açısından olumlu ve olumsuz deneyimler kazandıran sıkıntılı bir süreçtir. Bu süreçte hemşirenin ölümüne ilişkin tutumu, bakımın kalitesini etkilemektedir. Kalitesiz bir yaşam sonu dönem, bazı hastaların kendi yaşamlarını kolayca ve çabuk sona erdirmek için hekim ya da hemşireden yardım isteyebilmesine neden olmaktadır. Bu noktada hemşirelerin yüzleşmesi gereken bir etik sorun kümesi olarak ötanazi karşımıza çıkmaktadır. ${ }^{6}$

Bilim ve teknolojideki gelişmelerin tıp alanına yansımalarından biri uzayan insan ömrü ve biyomedikal materyaller ve tıbbi cihazlarla yaşamı farklı ortamlarda sürdürme olanağıdır. Bu uzama bireyin yaşama ve ölme hakkının; yaşamı bu derece ızdırap verici koşullarda sürdürme isteğinin; onurlu ölme hakkının sorgulanmasına yol açmaktadır. Bu bağlamda tıp etiği sorun kümelerinden ötanazi, gerek uygulanış yolu gerekse eylemin niteliği bağlamında farklı şekilde karşımıza çıkmaktadır. ${ }^{7,8}$ Ülkemizde ötanazi yasal olmamakla beraber tıp etiği tartışma konuları içinde varlığını sürdürmektedir. Hipokratik tıp anlayışından günümüze kadar hastanın ağrı ve acısının giderilmesi hekimin vazifesi olarak görülmüştür. Kişinin ağrı ve acısı olmaksızın ölümü kolaylaştırıcı süreç olarak ortaya çıkan ötanazi, huzur içinde en az düzeyde ağrı ile ölmesine işaret etmektedir. ${ }^{9}$ Pugno hekimin mesleğini icra ederken hasta yaşamını korumayı, acısını azaltmayı hedeflediğine vurgu yapmaktadır. ${ }^{10}$ Hasta için iyi olanı yapmada hekim karar verici durumda olmakta ve yaşamın sonu ile ilgili konularda hasta adına iyi kararı verirken zorluk çekmektedir. ${ }^{11}$

Hekimin ve diğer sağlık profesyonellerinin hastasının yaşamını sonlandıracak eylemde bulunmaması vurgulanmıştır. Bu süreç hemşireler için de geçerlidir. Bakım ve tedavi hizmetini 24 saat sürdüren hemşireler hasta adına en iyi kararı verirken zaman zaman zorlanmakta, güç anlar yaşamaktadır. Sağlığı koruma ve geliştirmeye yönelik Ölüm ve ölümcül hasta ile ilgili durumlar tüm sağlık profesyonellerinin karşısında aciz kaldığı, karşılaşmak istemediği bir durumdur. Hemşireler, hastaya bütüncül yaklaşım felsefesi çerçevesinde hastanın ölümle ilgili düşünce ve duygularını da daha iyi değerlendiren ve anlayabilen profesyonellerdir. 
Ölüm, ölümcül hasta, ötanazi kavramları ile iç içe çalışırken hemşirelerin bu konulara ilişkin görüşleri, davranışları, algıları ve mevcut tutumlarının belirlenmesi, bunların terminal dönem hasta bakımındaki etkilerinin ortaya konması, bu konularla ilgili sorularının cevabının bulunmaya çalışılması önem kazanmaktadır. Hemşirelerin öncelikle yaşamın son dönemine ilişkin kendi görüşlerinin olması ve bunun üzerine mesleki bilgi ve deneyimini katarak bakım vermesi söz konusudur. Bu çalışmanın da çıkış noktası yoğun bakımda hizmet veren sağıık profesyoneli hemşirelerin ölüm, ölümcül hasta ve ötanazi hakkındaki tutumlarını belirlemektir.

Hemşirelerin terminal dönemdeki hastaya hizmet verirken yüzleşmeleri gereken kavramlardan biri ötanazidir. Akademik düzeyde yapılan sınırlı sayıda çalışma dışında ötanazi ile ilgili bağlantılı etkinlikler, çalışmalar sınırıdır. Sağlık profesyonellerinin ötanazi hakkındaki düşüncelerinin yansıtılması bu konudaki bilimsel tartışmalara katacak, tıp etiği ile ilgili bu konu hakkında farkındalık artışına neden olacaktır. "Ölüme terk", "acıma ile öldürme", "onurlu ölüm”, "ölüm hakkı", kimilerine göre ise "cinayet/adam öldürme" olarak yorumlanan ötanazi zaman zaman güncel olaylarla tartışma konuları arasında yer almaktadır. Ötanazi; tıbbın elinde bulundurduğu olanaklarla iyileştiremediği ve nitelikli bir yaşam da sağlayamadığı hastaların yaşamlarının, içinde bulundukları belli koşullarda ve biçimde sona erdirilmesi olarak tarif edilmektedir. ${ }^{12,13}$

Ölümcül hasta ile bu kadar iç içe çalışırken hemşirelerin ölüm, ötanazi konularına ilişkin görüşleri ve mevcut tutumları önem kazanmaktadır. Bu çalışmanın amacı da ülkemizin güney ucunda yer alan biri diğerine göre görece daha yeni hizmet vermeye başlayan iki farklı üniversite hastanesinin yoğun bakım ünitesinde görev alan hemşirelerin ötanazi, ölüm, ölümcül hastaya yaklaşım konusundaki tutumlarını belirlemektir.

\section{Gereç ve Yöntem}

Tanımlayıcı tipte planlanan araştırmanın evrenini Mustafa Kemal Üniversitesi Hastanesi yoğun bakım ünitelerinde çalışan 87 hemşire ve Çukurova Üniversitesi Hastanesi yoğun bakım ünitelerinde çalışan 280 hemşire oluşturmuştur. Araştırmada örneklem seçimine gidilmemiş, ulaşılabilen ve çalışmaya katılmayı kabul eden 243 yoğun bakım hemşiresi araştırmanın örneklemini oluşturmuştur. Çalışmada katılımcıların $\% 66,21$ 'ine ulaşılmıştır. Çalışmada araştırmacılar tarafından katılımcılara bilgi verilmiş ve çalışmaya katılmayı kabul edenlere veri toplama formu dağıtıımıs ve doldurmaları istenmiştir.

Veri toplama aracı iki kısımdan oluşmaktadır. İlk kısımda katılımcıların sosyodemografik özelliklerini belirlemeye yönelik sorular; ikinci kısımda ise "Ötanazi, Ölüm ve Ölümcül Hastaya İlişkin Tutum Ölçeği (ÖTÖ)” yer almaktadır.

Araştırmacılar tarafından literatür taranarak hazırlanan 16 soruluk kişisel bilgi formu; yaş, cinsiyet, medeni durum, mezun olunan okul, çalışma yılı, çalıştığı birim, ölüm ve ötanazi ile ilgili tutumları belirlemeye yönelik soruları içermektedir. ${ }^{14-18}$

Ötanazi, Ölüm ve Ölümcül Hastaya İlişkin Tutum Ölçeği (ÖTÖ) 1996 yılında Şenol ve arkadaşları tarafından geliştirilmiş, Cronbach alfa değeri 0.84 olarak belirlenmiştir. ${ }^{19}$ Çalışmamızda ise Cronbach alfa değeri 0.78 bulunmuştur. Dörtlü likert tipi ölçek, 31 maddeden oluşmakta ve tümüyle katılıyorum=1, kısmen katılıyorum=2, pek katılmıyorum $=3$, hiç katılmıyorum $=4$ şeklinde puan hesabı yapılmaktadır. ${ }^{1,19}$ Ölçekten en fazla 124, en az 31 puan alınmaktadır. Ölçeğin 3, 6, 7, 8, 10, 12, 13, 15, 16, 17, 20, 23, 24 ve 27 numaralı maddeleri ters puanlanmaktadır. Ölçek üç alt boyuttan oluşmakta; bu alt boyutlarda ötanazi, ölüm ve ölümcül hastaya ilişkin tutumlar değerlendirilmektedir. ${ }^{1,19}$ Ölçeğin 1 , 2, 5, 6, 9, 12, 14, 16, 18, 19, 21, 22, 26, 29 numaralı maddeleri ötanazi; 4, 13, 15, 17, 20, 23, 25, 27, 30 numaralı maddeleri ölüm ve 3, 7, 8, 10, 11, 24, 28, 31 numaralı maddeleri ölümcül hastaya ilişkin tutumları belirlemeye yöneliktir. ${ }^{1,19}$ Ötanaziye ilişkin tutumu ölçen alt boyuttan en fazla 56, en az 14 puan; ölüme ilişkin tutumu ölçen alt boyuttan en fazla 36, en az 9 puan; ölümcül hastaya ilişkin tutumu ölçen alt boyuttan en fazla 32, en az 8 puan alınmaktadır. 
Ölçekten alınan toplam puanın artması ötanazi, ölüm ve ölümcül hastaya ilişkin tutumun daha olumsuz olduğu biçiminde değerlendirilmektedir. ${ }^{1,19}$

Araştırmanın etik kurul izni Mustafa Kemal Üniversitesi Tıp Fakültesi Etik Kurulu 06.05.2015 tarihli toplantı 23 karar no ile alınmıştır. Çalışma öncesinde çalışmanın yapılacağı kurumlardan yazııı izin alınmıştır.

Verilerin değerlendirilmesinde frekans dağılımı, Independent Sample t Test, One-Way Anova testi, Tukey testi kullanılmıştır.

\section{Bulgular}

Tablo 1'de katılımcıların sosyo - demografik özellikleri yer almaktadır. Katılımcıların yaş ortalaması 26,71, çalışma yılı ortalaması 5,84 yıl olarak bulunmuştur. Katılımcıların yaklaşık \%85'i kadın, \%47.7'si evli, \%69.5'i lisans mezunu, \%71.6'sı B Üniversitesi Hastanesi yoğun bakım ünitelerinde çalışmaktadır.

Tablo 1. Hemşirelerin Tanıtıcı Özellikleri

\begin{tabular}{llc}
\hline Bireysel Özellikler & Sayı (n=243) & Yüzde \\
\hline Hastane & & \\
Çukurova Üniversitesi & 174 & 71.6 \\
Mustafa Kemal Üniversitesi & 69 & 28.4 \\
Cinsiyet & & \\
Kadın & 206 & 84.8 \\
Erkek & 37 & 15.2 \\
Yaş (ort=27.61, SS=5.92) & & \\
19-23 & 76 & 31.3 \\
24-28 & 71 & 29.2 \\
29-33 & 55 & 22.6 \\
30 ve üst & 41 & 16.9 \\
Medeni Durum & & \\
Evli & 116 & 47.7 \\
Bekar & 127 & 52.3 \\
Eğitimi & & \\
Sağlık Meslek Lisesi & 43 & 17.7 \\
Önlisans & 23 & 9.5 \\
Lisans & 169 & 69.5 \\
Lisansüstü & 8 & 3.3 \\
Çalışma yılı (ort=5.84, SS=5.37) & & 6.2 \\
1-5 & 153 & 63.0 \\
6-10 & 59 & 24.3 \\
11-15 & 15 & 6.2 \\
16 ve üst & 16 & \\
\hline & & \\
\hline & & \\
\hline & & \\
\hline
\end{tabular}

Tablo 2'de hemşirelerin çalıştıkları birime göre bulgular yer almaktadır. Katılımcıların \%32.5'i pediatri/ yenidoğan yoğun bakımda, \%14.0'ü dahiliye yoğun bakımda, \%11.5'i cerrahi yoğun bakımda çalışmaktadır. Katıımcıların şu anki birimde çalışma yıl ortalaması 3,90 bulunmuştur. Şu an bulundukları yoğun bakım biriminde \%67,1'i 1-3 yıl, \%18,5'i 4-6 yıl ve \%14,4'ü 7 yıl ve üzeri çalışmaktadır. Katılımcıların yarısından fazlası (\%56) yoğun bakımı eğitimi almamış olup; yoğun bakım eğitimi alanların oranı \%44 olup bunların \%55.14'ü yoğun bakım kursu \%20,56'sı çiYAD (Çocuklarda ileri Yaşam Desteği) kursu, \%17.75'i Yenidoğan+NRP (Yenidoğan Canlandırma Programı) kursu ve \%6,55'i hizmet içi eğitim aldığını belirtmiştir.

Veri toplama formunda katılımcıların etik eğitimi alıp almamaları ile ilgili üç soru da katılımcıların \%70.0'i eğitimleri sırasında etik eğitimi aldığını; bunların \%85.9'u etik ile ilgili konuları okulda ders olarak aldıklarını; \%7.05'i etik ile ilgili kurslara katıldığını; \%7.05'i de etik ile ilgili kongrelere katıldığını belirtmiştir.

Tablo 3'de katılımcıların ölüme tanıklık durumlarını belirlemeye yönelik sorular yer almaktadır. 
Tablo 4' de katılımcıların ölçekten aldıkları puan ortalamaları yer almaktadır. ÖTÖ puan ortalaması 85,07'dir. Bu puan yüksek olup katılımcıların ölüm, ölümcül hasta ve ötanaziye yaklaşımlarının olumsuz olduğunu göstermektedir. Ölçeğin üç alt boyutundaki puan ortalamaları ise ötanaziye ilişkin tutum alt boyutu için 36,09; ölüme ilişkin tutum alt boyutu 25.57; ölümcül hastaya ilişkin tutum alt boyutu 23.40'dır. Katılımcıların ölümcül hastaya ilişkin tutumlarının daha olumlu olduğu görülmektedir.

Tablo 2. Hemşirelerin Çalışma Yaşamına Ait Bulgular

\begin{tabular}{llc}
\hline & Sayı (n=243) & Yüzde \\
\hline Çalıstı̆̆ı Yoğun Bakım & & 32.5 \\
Pediyatri/yenidoğan & 79 & 14.0 \\
Dahiliye & 34 & 11.5 \\
Genel cerrahi & 28 & 10.7 \\
Kardiyoloji & 26 & 9.9 \\
Beyin cerrahisi & 24 & 9.5 \\
Reanimasyon & 23 & 6.6 \\
Kardiyovasküler cerrahi & 16 & 5.3 \\
Nöroloji & 13 & \\
Şu anki birimde çalışma yılı (ort=3.90, SS=4.24) & & 67.1 \\
1-3 & 163 & 18.5 \\
4-6 & 45 & 14.4 \\
7 ve üst & 35 & \\
Yoğun bakım eğitimi aldınız mı? & & 44.0 \\
Evet & 107 & 56.0 \\
Hayır & 136 & \\
Yoğun bakım eğitimi türü (n=107) & & 55.3 \\
YB (yoğun bakım) kursu & 59 & 20.5 \\
Çocuklarda İleri Yaşam Desteği Kursu & 22 & 17.7 \\
Yenidoğan kursu+ Yenidoğan Canlandırma Programı & 19 & 6.5 \\
Hizmet içi eğitim & 7 & \\
\hline
\end{tabular}

Tablo 3. Katılımcıların Ölümle İlgili Görüşleri

\begin{tabular}{lll}
\hline & Sayı (n=243) & Yüzde \\
\hline Yakınına ölümcül hastalık tanısı konma deneyimi yaşama & & 42.8 \\
Evet & 104 & 57.2 \\
Hayır & 139 & 39.9 \\
Yakınının ölümüne hastanede tanık olma & & 60.1 \\
Evet & 97 & \\
Hayır & 146 & 39.5 \\
Yakınının ölümüne evde tanık olma & & 60.5 \\
Evet & 96 & \\
Hayır & 147 & 22.2 \\
Kendi ölümünü düşünme sıklığı & & 63.8 \\
Çok sık & 54 & 14.0 \\
Ara sıra & 155 & \\
Çok seyrek/hiç & 34 & 24,3 \\
Aileye ölüm haberini verme işi size düşerse & & 61.7 \\
Normal karşılarım & 59 & 14.0 \\
Güçlük çekerim & 150 & \\
Söylemem & 34 & 69.1 \\
Aileye ölüm haberini kim vermeli & & 4.2 \\
Doktor & 168 & 26.7 \\
Hemşire & 10 & \\
Doktor-Hemşire birlikte & 65 & \\
\hline
\end{tabular}


Tablo 4. Katılımcıların Ötanazi, Ölüm ve Ölümcül Hastaya Illişkin Tutum Ölçeği'nden Aldıkları Puan Ortalamaları

\begin{tabular}{llll}
\hline & $\mathbf{x} \pm$ SS & $\begin{array}{l}\text { Ölçekten alınabilecek } \\
\mathbf{m i n}-\operatorname{max~değer~}\end{array}$ & $\begin{array}{l}\text { Ölçekten alınan } \\
\text { min- max değer }\end{array}$ \\
\hline $\begin{array}{l}\text { Ötanazi, Ölüm ve Ölümcül Hastaya İlişkin } \\
\text { Tutum Ölçeği }\end{array}$ & $85,07 \pm 9,75$ & $31-124$ & $51-108$ \\
Ötanaziye İlişkin Tutum Alt Boyutu & $36,09 \pm 7,72$ & $14-56$ & $14-52$ \\
Ölüme İlişkin Tutum Alt Boyutu & $25.57 \pm 2.78$ & $9-36$ & $18-33$ \\
Ölümcül Hastaya İlişkin Tutum Alt Boyutu & $23.40 \pm 2.73$ & $8-32$ & $15-29$ \\
\hline
\end{tabular}

Tablo 5'de katılımcıların tanıtıcı özelliklerine göre ÖTÖ puanları yer almaktadır.

Tablo 5. Katılımcıların Tanıtıı Özellikleri ve Ötanazi, Ölüm ve Ölümcül Hastaya İlişkin Tutum Ölçeği Puan Ortalamaları

\begin{tabular}{|c|c|c|c|c|c|}
\hline Tanıtıcı özellik & $n=243$ & $\begin{array}{l}\text { Ötanazi, Ölüm ve } \\
\text { Ölümcül Hastaya } \\
\text { İlişkin Tutum Ölçeği } \\
\text { Toplam Puan } \\
\text { Ortalaması } \\
\text { X } \pm \text { SS }\end{array}$ & $\begin{array}{l}\text { Ötanaziye İlişkin } \\
\text { Tutum Alt Boyutu } \\
\text { Puan Ortalaması }\end{array}$ & $\begin{array}{l}\text { Ölüme İlişkin } \\
\text { Tutum Alt Boyutu } \\
\text { Puan Ortalaması }\end{array}$ & $\begin{array}{l}\text { Ölümcül Hastaya } \\
\text { İlişkin Tutum Alt } \\
\text { Boyutu } \\
\text { Puan Ortalaması } \\
\text { X士SS }\end{array}$ \\
\hline \multicolumn{6}{|l|}{ Üniversite } \\
\hline Çukurova Üniversitesi & 174 & $85.79 \pm 9.91$ & $36.50 \pm 7.62$ & $25.64 \pm 2.75$ & $23.64 \pm 2.73$ \\
\hline Mustafa Kemal Üniversitesi & 69 & $\begin{array}{l}83.26 \pm 9.69 \\
t=1.837, p=0,067\end{array}$ & $\begin{array}{l}35.07 \pm 7.94 \\
t=1.306, p=0,193\end{array}$ & $\begin{array}{l}25.39 \pm 2.86 \\
t=0.637, p=0.525\end{array}$ & $\begin{array}{l}22.79 \pm 2.67 \\
t=2.205, p=0,028\end{array}$ \\
\hline \multicolumn{6}{|l|}{ Yaş } \\
\hline $19-23$ & 76 & $86.26 \pm 9.18$ & $36.52 \pm 7.28$ & $25.98 \pm 2.59$ & $23.75 \pm 2.26$ \\
\hline $24-28$ & 71 & $82.66 \pm 7,53$ & $34.50 \pm 6.90$ & $25.16 \pm 3.22$ & $22.98 \pm 2.70$ \\
\hline $29-33$ & 55 & $84.34 \pm 13.75$ & $35.27 \pm 9.66$ & $25.45 \pm 2.95$ & $23.61 \pm 3.61$ \\
\hline \multirow[t]{2}{*}{30 ve üst } & 41 & $88.04 \pm 6.43$ & $39.17 \pm 6.07$ & $25.65 \pm 1.86$ & $23.21 \pm 2.13$ \\
\hline & & $F=3.286, p=0,022$ & $F=3.560, p=0,015$ & $F=1.180, p=0,346$ & $F=1.132, p=0,337$ \\
\hline \multicolumn{6}{|l|}{ Çalışma yılı } \\
\hline $1-5$ & 153 & $83.62 \pm 10.26$ & $34.86 \pm 7.95$ & $25.48 \pm 2.94$ & $23.27 \pm 2.84$ \\
\hline $6-10$ & 59 & $87.03 \pm 9.05$ & $37.59 \pm 7.16$ & $25.69 \pm 2.75$ & $23.74 \pm 2.68$ \\
\hline $11-15$ & 15 & $87.13 \pm 6.88$ & $38.40 \pm 6.87$ & $25.46 \pm 1.35$ & $23.26 \pm 2.60$ \\
\hline \multirow[t]{2}{*}{16 ve üst } & 16 & $89.81 \pm 6.45$ & $40.18 \pm 5.62$ & $26.05 \pm 2.35$ & $23.56 \pm 2.06$ \\
\hline & & $F=3.500, p=0,016$ & $F=4.115, p=0,007$ & $F=0.261, p=0.854$ & $F=0.448, p=0,719$ \\
\hline \multicolumn{6}{|l|}{ Klinikte çalışma yılı } \\
\hline $1-3$ & 163 & $83.61 \pm 10.67$ & $34.90 \pm 8.10$ & $25.42 \pm 2.89$ & $23.27 \pm 2.88$ \\
\hline 4-6 & 45 & $87.91 \pm 6.94$ & $37.64 \pm 5.86$ & $26.37 \pm 2.40$ & $23.88 \pm 2.47$ \\
\hline \multirow[t]{2}{*}{7 ve üst } & 35 & $88.25 \pm 6,38$ & $39.65 \pm 6.70$ & $25.20 \pm 2.56$ & $23.40 \pm 2.29$ \\
\hline & & $F=5.813, p=0,003$ & $F=6.862, p=0,001$ & $F=2.445, p=0.089$ & $F=0.882, p=0,415$ \\
\hline \multicolumn{6}{|c|}{$\begin{array}{l}\text { Bir yakınınıza ölümcül hastalık } \\
\text { tanısı konması deneyimini yaşama }\end{array}$} \\
\hline Evet & 104 & $82.87 \pm 10.28$ & $34.15 \pm 7.77$ & $25.72 \pm 2.34$ & $23.00 \pm 2.90$ \\
\hline Hayır & 139 & $\begin{array}{l}86.72 \pm 9.03 \\
t=-3.098, p=0,002\end{array}$ & $\begin{array}{l}37.55 \pm 7.39 \\
t=-3.470, p=0,001\end{array}$ & $\begin{array}{l}25.46 \pm 3.07 \\
t=0.722, p=0,471\end{array}$ & $\begin{array}{l}23.71 \pm 2.57 \\
t=-2.019, p=0,045\end{array}$ \\
\hline \multicolumn{6}{|c|}{$\begin{array}{l}\text { Bir yakınınızın hastane ortamında } \\
\text { ölme sürecine tanık olma }\end{array}$} \\
\hline Evet & 97 & $82.51 \pm 10.30$ & $34.41 \pm 8.37$ & $25.36 \pm 2.48$ & $22.74 \pm 2.67$ \\
\hline Hayır & 146 & $\begin{array}{l}86.78 \pm 9.01 \\
t=-3.410, p=0,001\end{array}$ & $\begin{array}{l}37.21 \pm 7.07 \\
t=-2.812, p=0,005\end{array}$ & $\begin{array}{l}25.71 \pm 2.95 \\
t=-0.965, p=0,336\end{array}$ & $\begin{array}{l}23.84 \pm 2.69 \\
t=-3.142, p=0,002\end{array}$ \\
\hline \multicolumn{6}{|l|}{ Kendi ölümünü düşünme sıklığı } \\
\hline Çok sık & 54 & $82.44 \pm 7.75$ & $34.92 \pm 6.38$ & $24.51 \pm 2.40$ & $23.00 \pm 2.48$ \\
\hline Ara sıra & 155 & $87.05 \pm 8.25$ & $37.32 \pm 7.02$ & $25.94 \pm 2.81$ & $23.79 \pm 2.44$ \\
\hline \multirow[t]{2}{*}{ Çok seyrek/hiç } & 34 & $80.23 \pm 15.14$ & $32.38 \pm 10.89$ & $25.55 \pm 2.84$ & $22.29 \pm 3.87$ \\
\hline & & $F=10.045, p=0,003$ & $F=6.808, p=0,001$ & $F=5.439, p=0.005$ & $F=5.117, p=0,007$ \\
\hline \multicolumn{6}{|l|}{$\begin{array}{l}\text { Ölüm haberini verme işi size } \\
\text { düşerse ne yaparsınız? }\end{array}$} \\
\hline Normal kabul eder söylerim & 59 & $79.83 \pm 11.15$ & $33.11 \pm 8.86$ & $24.72 \pm 2.99$ & $21.98 \pm 2.99$ \\
\hline $\begin{array}{l}\text { Nasıl söyleyeceğime karar } \\
\text { vermekte güçlük çekerim }\end{array}$ & 150 & $86.71 \pm 8.75$ & $37.04 \pm 7.33$ & $25.86 \pm 2.51$ & $23.80 \pm 2.48$ \\
\hline \multirow[t]{2}{*}{ Kaçarım, söylemek istemem } & 34 & $86.97 \pm 8.25$ & $37.08 \pm 6.00$ & $25.76 \pm 3.25$ & $24.11 \pm 2.54$ \\
\hline & & $F=12.335, p=0,000$ & $F=6.035, p=0,003$ & $F=3.678, p=0.027$ & $F=11.664, p=0,000$ \\
\hline
\end{tabular}


Katılımcıların çalıştığı kurum ile ölçekten aldıkları puan ortalamaları arasındaki anlamlı fark sadece ölümcül hastaya ilişkin tutum alt boyutunda bulunmuştur $(p<0.005)$. Çukurova Üniversitesi'nde görev yapan hemşirelerin ölümcül hastaya ilişkin tutum alt boyutu puan ortalaması daha yüksek olduğu bulunmuştur.

Veri toplama formunda son soruda katılımcılardan ötanaziyi bir cümle ile tanımlamaları istenmişti. Bu soruya 141 katılımcı yanıt vermiştir. Yanıt veren katılımcılardan 40'ı "kişinin kendi isteği ile yaşamını sonlandırmak istemesi”, 24 tanesi ötanaziyi "ağrısız/acısız ölüm”, 17'si“ölme hakkı”, 17 tanesi "hastalığın son evresinde, tedavisi olmayan hiçbir şeye yanıt vermeyenlerde hayatın sonlandırılması", 5'i "hastalığının son evresinde hastaya uygulanan tüm yaşam desteklerinin sonlandırılması" 4 tanesi "cinayet" olarak tanımlamıştır. Bu soruya 8 katılımcı "ötanaziye katılmıyorum", diğerleri ise farklı yanıtlar vermiştir.

\section{Tartışma}

Çalışmamızda ÖTÖ puan ortalaması 85.07 bulunmuştur. Ortalama puan üzerinde değerlendirme yapıldığında katılımcıların ötanazi, ölüm, ölümcül hastaya ilişkin tutumlarının olumsuz olduğu görülmektedir. Alt grupların puan ortalamalarına bakıldığında ötanaziye ilişkin tutum alt boyutu için 36,09, ölüme ilişkin tutum alt boyutu için 25.57, ölümcül hastaya ilişkin tutum alt boyutu için $23.40^{\prime}$ dır. Alt gruplar arasında bir değerlendirme yapıldığında katılımcıların ölümcül hastaya ilişkin tutumlarını diğer iki alt boyuta göre daha olumsuz olduğu; ötanaziye karşı daha olumlu bir yaklaşım benimsedikleri görülmektedir. Ölüm ve ötanazi hemşireler tarafından daha kabul gören yaklaşımlardır. Ölümcül hastalığı olan bireylere verilen sağlık hizmeti sırasında hemşireler hastaları ile etkileşmeleri sırasında güçlük yaşayabilirler. Özellikle hasta ile sürecin konuşulması ve hastanın duygularını ifade etmesi hemşireliğin güç yanlarından biri olduğunu söylemek mümkündür. Çünkü burada verilen hizmet sadece hasta konforunu sağlamaya yönelik olup iyileşmenin söz konusu olmadığı durumlardır. Tıp ve hemşirelik öğrencilerinin ötanaziye ilişkin tutumlarını belirlemeye yönelik aynı ölçek kullanılarak yapılan bir çalışmada katılımcıların ortalama puanı 82,79 bulunmuştur. ${ }^{20}$ Bu sonuç çalışmamız sonuçları ile benzerlik göstermektedir. Hemşirelerin ölüm kaygısı, ölüme ilişkin depresyon durumları ve ölmek üzere olan hastaya yaklaşımlarını incelediği çalışmasında İnci, ÖTÖ puan ortalamasını bizim çalışmamıza göre daha düşük (73.38) bulmuştur. ${ }^{21}$ Hemşirelik öğrencilerinin ötanaziye ilişkin tutumlarını inceleyen çalışmada kendileri $(\% 21,5)$ ve yakınları $(\% 16,7)$ için ötanaziyi kabul eden öğrencilerin oranı acı çeken, ölümcül bir hasta için ötanaziyi isteme $(\% 30,9)$ oranlarından daha düşük bulunmuştur. ${ }^{22}$ Hemşire ve hekimler üzerinde yapılan çalışmada hemşirelerin \%31,5'i kendisi, \%13,0'ü yakını için; hekimlerin \%43,5'i kendisi, \%25,0'i yakını için ötanazi isteyeceğini belirtmiştir. ${ }^{16} \mathrm{Ayn}$ çalışmada katılımcıların ötanaziyi kabul etme nedenleri arasında ilk sırada acı çekmemek yer almaktadır. ${ }^{16}$ Literatürde yer alan çalışmalarda benzer sonuçlar bulunmuştur. ${ }^{14,15,23}$ Farklı birimlerde çalışan hemşirelerin ötanaziye yaklaşımını belirleyen çalışmada "Sizce bireyin kendi yaşamına son verme konusunda karar verme hakkı var mıdır?" sorusuna en çok evet cevabını veren hemşirelerin yoğun bakımda çalışanların, (\%73.1) en az evet cevabını verenlerin çocuk kliniklerinde (\%48.5) çalışan hemşireler olduğu bulunmuştur. ${ }^{17}$ Yetişkin ve yenidoğan yoğun bakım ünitelerinde çalışan hemşireler üzerinde yapılan çalışmada hemşirelerin ötanaziye ilişkin olumsuz tutuma sahip oldukları saptanmıştır. ${ }^{24}$ Doktor ve hemşirelerin ötanaziye ilişkin tutumlarını belirlemeye yönelik yapılan çalışmada katılımcıların yarıdan fazlasının ötanaziye olumlu bakmadıkları saptanmıştır. ${ }^{25}$

Üniversitelere göre ÖTÖ puan ortalaması ve alt grup puan ortalaması arasındaki karşılaştırmada ölümcül hastaya ilişkin tutum alt boyutunda anlamlı fark bulunmuştur $(p<0,005)$. Çukurova Üniversitesi Hastanesi daha köklü, hasta kapasitesi fazla ve vaka çeşitliliği olan bir hastanedir. Dolayısıyla hem yatak kapasitesi hem de hem de hemşire sayısı daha fazladır. Burada görev yapan yoğun bakım hemşirelerinin deneyimleri ve hasta çeşitlilikleri daha fazladır. Bu çalışmada temel amaç mevcut durumu ortaya koymak olup üniversiteler arasında diğer verilerle karşılaştırma yapılmamıştır. 
Çalışmamızda yaş grupları ile ÖTÖ toplam puan ortalaması ve ötanaziye ilişkin tutum alt boyutu puan ortalaması arasında anlamlı fark $(p<0,005)$ olup 30 yaş ve üstü katılımcıların puan ortalamaları diğerlerine göre daha yüksek bulunmuştur. İnci'nin çalışmasında ölüme dair verilen eğitimin yaş gruplarına göre ötanazi, ölüm, ölümcül hastaya tutuma ilişkin değişiklik yaratmadığı saptanmıştır. ${ }^{21}$ Özkiriş ve ark çalışmasında hekimlerin ölüm kaygısı yaşama düzeyi ile yaşı arasında anlamlı fark bulunmamıştır. ${ }^{26}$ Çalışmamızda 30 yaş ve üzeri hemşirelerin ötanaziye ilişkin tutumlarının olumsuz olduğu saptanmıştır. Yaşın ilerlemesi ile mesleki deneyimin artması katılımcılarda yaşama son vermeye yönelik tutumun kabulünü olumsuz etkilemiş olabileceği düşünülmektedir.

Çalışma yılı ile ÖTÖ toplam puan ortalaması ve ötanaziye ilişkin tutum alt boyutu puan ortalaması arasında anlamlı fark $(p<0,005)$ bulunmuştur. Çalışma yılı 16 ve üzeri olan katılımcılarda ÖTÖ toplam puan (89.81) ve ötanaziye ilişkin puan ortalaması (40.18) yüksektir ki bu da tutumlarının olumsuz olduğunu göstermektedir. Çalışma yııının artması dolayısıyla mesleki deneyimin artması yaşamın sonuna dair etik konulardaki tutumu etkileyebilmektedir. İnci'nin eğitimin ötanazi, ölüm ve ölümcül hastaya ilişkin tutumu incelediği çalışma yılının tutumu değiştirmediği saptanmıştır ${ }^{21}$. Uysal ve arklarının hekimler üzerinde yaptığı çalışmada çalışma yıına göre ötanaziye ilişkin tutum arasında anlamlı fark bulunmamıştır. ${ }^{27}$ Özkıriş ve arklarının benzer çalışmasında hekimlerin ölüm kaygısı yaşama düzeyi ile meslek yaşı arasında anlamlı fark bulunmamıştır. ${ }^{26}$ Aynı çalışmada ölümcül hasta ve ölümle karşılaşma sıklığı ile ölüm kaygısı arasında anlamlı fark olduğu saptanmış, karşılaşma sıklığı artan grupta kaygı düzeyi daha az bulunmuş olup hemşirelerin meslek yaşı ile ölüm kaygı düzeyi arasında anlamlı fark bulunmuş çalışma yılı arttıkça kaygı düzeyinin arttığı saptanmıştır. ${ }^{26}$

Yoğun bakım kliniğinde çalışma süresi ile tutum ölçeği puan ortalamaları arasındaki ilişkiye baktığımızda ÖTÖ toplam puan ortalaması ve ötanaziye ilişkin tutum alt boyutu puan ortalaması arasında anlamlı fark $(p<0,005)$ bulunmuştur. Çalışma yılı üç ve üçten az olan katılımcılarda puan ortalamaları daha düşük bulunmuş olup genel ve ötanaziye karşı tutumlarının daha olumlu olduğu görülmektedir. Yapılan bir çalışmada yoğun bakımda çalışma süresi ile ölüm kaygı ölçeği puan ortalaması arasında anlamlı fark bulunmamıştır. ${ }^{29}$ Yoğun bakım hemşireleri üzerinde yapılan çalışmada yoğun bakım ünitelerinde çalışma yılı düşük olan hemşirelerin aktif ve pasif ötanaziye daha olumlu baktıkları bulunmuştur. ${ }^{28}$ Çalışmamızda da benzer sonuçlar elde edilmiş olup yoğun bakım kliniklerinde çalışma yılı yedi ve üzerinde olan hemşire sayısı az olup bunların ötanaziye yönelik tutumlarının ve genel olarak ölüm, ölümcül hasta ve ötanaziye ilişkin tutumlarının daha olumsuz olduğu bulunmutur.

Çalışmamızda bir yakınınıza ölümcül hastalık tanısı konması deneyimini yaşama ile puan ortalamaları arasındaki ilişkiye bakıldığında ÖTÖ toplam puanı, ötanaziye ve ölümcül hastaya ilişkin tutum alt boyutları arasında anlamlı fark bulunmuştur $(p<0,05)$. Bir yakınına ölümcül hastalık tanısı konma deneyimi yaşayanların tutumlarının daha olumlu olduğu görülmektedir. Böyle bir deneyimi yaşamının kişinin ölüm ve ölümcül hastaya bakış açısını etkilemesi beklenen bir durumdur. Sağlık profesyoneli olmanın kişinin kendi değerlerini gerçekleştirmesinde engel olmayacağı görülmektedir. Yapılan bir çalışmada hemşirelerin terminal dönemdeki hastaya bakımdan etkilenme biçimlerine göre, ölüm kaygısı, ölüme ilişkin depresyon ve ölümcül hastaya tutum ölçeğinden aldıkları puanlar arasında istatistiksel olarak anlamlı fark saptanmamıştır. ${ }^{21}$ Hemşirelik öğrencileri üzerinde yapılan çalışmada terminal dönemdeki hastaya bakım veren öğrencilerin \%72,7'si hastaların ötanazi hakkının olduğunu; \%69.4'ü ötenazi yasal olması gerektiğini düşündüklerini belirtmiş olup gruplar arasında anlamlı fark $(p<0,05)$ bulunmuştur. ${ }^{30}$ Diğer meslek grubu olan hekimlerin ölüm kaygı düzeyini belirlemen bir çalışmada ölümcül hasta ve ölümle karşılaşma sıklığı ile ölüm kaygısı arasında anlamlı fark olduğu saptanmış, karşılaşma sıklığı artan grupta kaygı düzeyinin daha az bulunmuştur. ${ }^{26}$ Tıp fakültesi öğrencileri üzerindeki çalışmada ölmekte üzere olan hastaya bakım vermeyen hekim adaylarının ölümcül hastayla daha çok iletişim güçlüğü yaşadığı saptanmıştır. ${ }^{18}$ 
Bir yakınınızın hastane ortamında ölme sürecine tanık olma ile puan ortalamaları arasındaki ilişkiye bakıldığında ÖTÖ toplam puan ile ötanaziye ve ölümcül hastaya ilişkin tutum alt boyutları arasında anlamlı fark bulunmuştur $(p<0,05)$. Böyle bir deneyimi yaşayanların ötanazi ve ölmek üzere olan hastaya ilişkin tutumlarının daha olumlu olduğu, bu deneyimin ölüme dair tutumu etkilemediği görülmektedir. Yoğun bakım hemşireleri üzerindeki çalışmada yakınını kaybeden katılımcıların ölüm kaygı ölçeği ortalama puanının daha yüksek olduğu saptanmıştır. ${ }^{29}$ Yoğun bakım hemşireleri üzerinde yapılan çalışmada ölüme tanıklık sayısının artması ile ölüm kaygısı düzeyi arasında anlamlı fark bulunmuştur. ${ }^{29} \mathrm{Bu}$ fark ayda yedi ve üzeri ölüme tanık olan hemşirelerde ölüm kaygı puan ortalamasının artması ile ilişkilidir. ${ }^{29}$ iran'da hemşireler üzerinde yapılan çalışmada ölmek üzere olan bir yakınının bakım sürecinde bulunan hemşirelerin yaşamın sonundaki hastaların bakımında daha çok yer aldıkları bulunmuştur. ${ }^{31}$ Tıp fakültesi öğrencileri üzerinde yapılan bir çalışmada katıımcıların cinsiyetine, ailede ölüm öyküsü olma durumuna göre ölümden ve ölümcül hastadan kaçınma arasında anlamlı fark bulunmamıştır. ${ }^{18}$ Bu çalışmada ölümcül hastaya ilişkin kaçınıcı davranışların arasında ölüm/ölümcül hastayla ilgili yaşantıları yok sayma, reddetme ya da mesleki yaşamlarının dışına itme eğilimi olduğu; ailesinde ölüm öyküsü olan katılımcıların ölüm ve ölümcül hastaya yaklaşım bağlamında daha az iletişim güçlüğü yaşadıkları ve daha az kaçınıcı davranışlar sergiledikleri saptanmıştır. ${ }^{18}$ Hekimlerin ölüme ilişkin tutumlarını belirleyen bir çalışmada ölüm ve ölümcül durumlar karşısında hekimlerin yaşadıkları; duygusal zorluklar, keder (\%71), çaresizlik (\%48), sıkıntı-anksiyete (\%42), kendini ve mesleğini sorgulama (\%24), yetersizlik-suçluluk (\%21) olarak belirlenmiştir. ${ }^{26}$

Kendi ölümünü düşünme sıklığı ile puan ortalamaları arasındaki ilişkiye bakıldığında ÖTÖ toplam puan ile ötanaziye ve ölüme ilişkin tutum alt boyutları arasında anlamlı fark bulunmuştur $(p<0,005)$. Kendi ölümünü ara sıra düşünen katılımcı sayısı oldukça fazla olup puan ortalamaları ölümü sık ya da çok seyrek/hiç düşünmeyenlerden daha fazla bulunmuştur. Ölümü düşünmeyen katılımcılarda ölüme ve ötanaziye yönelik tutum daha olumludur. Ölüme ilişkin kendi değerlerini düşünmemek, süreci çok sorgulamamaya neden olabilmektedir. Bu da ötanaziye yönelik tutumu daha olumlu yapabilmektedir. Bir çalışmada araştırmaya katılan hemşirelerin ölümü düşünme durumlarına göre Thorson-Powell Ölüm Kaygısı Ölçeği puan ortalamaları arasındaki farkın istatistiksel olarak anlamlı olduğu $(p<0.05)$. Ölümü seyrek düşünen hemşirelerin diğer hemşirelere göre Thorson-Powell Ölüm Kaygısı Ölçeği puan ortalamaları daha yüksek olduğu tespit edilmiştir. ${ }^{29}$ Bu sonuç çalışmamızla benzerlik göstermektedir.

“Ölüm haberini verme işi size düşerse ne yaparsınız?" sorusuna verilen yanıtlar ile puan ortalamaları arasındaki ilişkiye bakıldığında tüm puan ortalamaları arasında anlamlı fark bulunmuştur $(p<0,005)$. Ölüm haberini vermeyi normal kabul eden katılımcıların tüm ölçek ve alt boyutlarda puan ortalamaları diğerlerine göre daha düşük bulunmuştur. Ölümü yaşamın bir parçası olarak algılamak, mesleki pratik sırasında yaşama ve ölüme dair değerleri ve yaklaşımları daha kabul edilebilir görmeye yol açabilmektedir.

Hemşirelik öğrencilerine ötanazi uygulaması hakkındaki düşüncelerinin sorulduğu çalışmada en çok oranda verilen yanıtlar "Doğaya/Yaratana/Evrene karşı gelmek", "Tıbbi bir uygulama". "Cinayet ve kasten adam öldürmek", "insan-hasta hakkıdı", "Insan-hasta hakkı ihlalidir" şeklindedir. ${ }^{22}$ Beder ve arklarının hemşire ve hekimlerin ötanaziye ilişkin görüşlerini belirlediği çalışmada katılımcılar ötanazi konusundaki görüşlerini en çok "Hastanın yaşamak kadar ölmek de hakkıdır", "Tıbbi bir uygulamadır" ifadeleri ile belirtmiştir. ${ }^{16}$ Kumaş'ın çalışmasında ötanazi konusundaki düşüncelerini hemşirelerin \%55,9 ötanaziyi insan/hasta hakkı; $\% 42,5^{\prime} \mathrm{i}$ tıbbi bir uygulama olarak belirtmiştir. ${ }^{23}$ Çalışmamızda ise hiçbir katılımcı ötanaziyi tıbbi bir uygulama olarak tanımlamamıştır. Katılımcılarımızın yaklaşık \%41'i ölme hakkı olarak kişinin kendi isteği ile yaşamımı sonlandırmak istemesi \%17'si ağrısız/acısız ölüm olarak tanımlamış olup bu sonuçlar diğer çalışmalar ile benzerlik göstermektedir. Hekimlerin ötanaziye ilişkin tutumlarını belirlemeye yönelik yapılan çalışmada \%88.30' ötanaziyi kişinin kendi ölümünü istemesi, $\% 11.0^{\prime}$ i insan, hasta hakkı olarak tanımlamıştır. ${ }^{32}$ 
Hemşirelerin ötanaziye ilişkin tutumunu belirleyen çalışmada hemşirelerin yaklaşık \%60” ötanaziyi “kişinin kendi ölümünü istemesi" şeklinde tanımlamış ve yaklaşık \%60'ı ötanazi uygulamasını "doğaya, yaratana, evrene karşı gelme" olarak değerlendirdiklerini belirtmişlerdir. ${ }^{33}$ Sağlık profesyonellerinin ötanaziye yönelik tutumlarını belirleyen çalışmada ötanazi uygulamasını katılımcıların \%35'i insan/hasta hakkı, \%29'u tıbbi bir uygulama olarak değerlendirmiştir. ${ }^{34}$

Yoğun bakımda çalışan hemşirelerin çalıştıkları birimlere göre ölçekten aldıkları puan ortalamaları arasında çalışmamızda anlamlı bir fark saptanmamıştır $(p>0,05)$. Hemşireler üzerinde yapılan çalışmada benzer bir sonuç bulunmuştur. ${ }^{21}$ Özkiriş ve arkadaşlarının çalışmasında hekimlerin çalışma alanlarına göre ölüm kaygısı ölçeği puan ortalamaları arasında anlamlı fark bulunmuş olup bu farkın temel tıp bilimlerindeki hekimlerinin puan ortalamalarının diğerlerine göre daha yüksek olmasından kaynaklandığı belirtilmiştir. ${ }^{26} \mathrm{Hemşirelerin}$ çalıştıkları birimlere göre ötanazi konusundaki görüşlerini belirleyen bir çalışmada yoğun bakım hemşirelerinin \% 30'u ötanazinin yasallaşması gerektiğini belirtmiştir. ${ }^{14}$ Aynı çalışmada hemşirelerin hizmet verdikleri klinik ile ötanazi hakkındaki fikirleri arasında anlamlı fark bulunmamıştır $(p=0,005) \cdot{ }^{14}$ Bu sonuç çalışmamı bulguları ile paralel olup literartürde benzer çalışmalarda benzer sonuçlar elde edilmiştir. ${ }^{14,16}$ Yoğun bakım hemşireleri üzerinde yapılan bir çalışmada ölmek üzere olan hastanın bakımının sürdürülmesi gerektiğini belirten hemşirelerin saygın ölüm ilkelerine yönelik tutumlarının daha olumlu olduğu saptanmıştır. ${ }^{35}$ Çalışmamızda da katılımcıların ölümcül hastaya ilişkin tutumlarının olumlu olduğu saptanmıştır.

\section{Araştırmanın Sınırlılıkları}

$\mathrm{Bu}$ araştırma, her iki üniversite hastanesinin yoğun bakım kliniklerinde çalışan hemşireleri ile yapılmıştır. Araştırma, yapıldığı bölümlerdeki katılımcılar ile sınırlıdır. Bu doğrultuda araştırma hemşirelerin verdikleri cevaplar ile sınırlıdır.

\section{Sonuç}

Ortalama puan üzerinde değerlendirme yapıldığında katılımcıların ötanazi, ölüm, ölümcül hastaya ilişkin tutumlarının olumsuz olduğu görülmektedir. Katılımcılar tarafından ötanazi "kişinin kendi isteği ile yaşamını sonlandırmak istemesi", "ağrısı/acısız ölüm" gibi ifadelerle tanımlanmıştır. Katılımcıların ölümcül hastaya ilişkin tutumlarının diğer alt gruplara göre daha olumlu olduğu bulunmuştur. Ötanazi, ölüm, ölümcül hastaya ilişkin tutumlarının yaş, meslek yaşı, yoğun bakımda çalışma süresi, ölümle ilgili kişisel deneyimlerinden etkilendiği bulunmuştur.

\section{Bilgi}

Çalışmaya katılan tüm hemşirelere teşekkür ederiz. Makalenin yazarları arasında çıkar çatışması bulunmamaktadır.

\section{Kaynaklar}

1. Ay MA. Hemşirelerin ölüm, ölümcül hasta ve ötanaziye ilişkin tutumları. Tez Danışmanı Prof. Dr. Fatma Öz. Hacettepe Üniversitesi Sağlık Bilimleri Enstitüsü Psikiyatri Hemşireliği Programı Yüksek Lisans Tezi. Ankara: 2013.

2. Karahisar F. Ölümcül hasta, hemşire ve hekimlerin ölüm ve ötanaziye ilişkin görüşlerinin incelenmesi. Tez Danışmanı Doç. Dr. Mağfiret Kara Kaşıkçı. Atatürk Üniversitesi Sağlık Bilimleri Enstitüsü Hemşirelik Esasları Anabilim Dalı Yüksek Lisans Tezi. Erzurum: 2006.

3. Bach V, Ploeg J, Black M. Nursing roles in end-of-life decision making in critical care settings. Western Journal of Nursing Research 2009;31(4):496-512.

4. Langley G, Schmollgruber S. End-of-life care in intensive care units. SAJCC 2006;22(2):58-67.

5. Ersoy N, Altun i. Hemşirelerin yardımlı intihar hakkında görüşleri ile ilgili bir çalışma. Türkiye Klinikleri J Med Ethics 2001;9(1):4955.

6. Aypar Ü. Ötenazi. Hacettepe Tıp Dergisi 1997;28(1):43-7

7. Çobanoğlu N. Ötanazi. Kuramsal ve Uygulamalı Tıp Etiği. Eflatun Yayınevi, Ankara; 2009. pp: 203-13. 
8. Ersoy N. Ötanazi ve yardımlı intihar. Çağdaş Tıp Etiği. Editör: Demirhan Erdemir A, Öncel Ö, Aksoy Ş. Nobel Tıp Kitabevi, İstanbul; 2003. pp: 328-57.

9. Essex KH. Euthanasia. TMSJ 2000;11(2):191-212.

10. Pugno PA. One physician's perspective: Euthanasia and physician-assisted suicide. Health Care Analysis 2004;12(3):215-223.

11. Fenigsen R. Other people's lives: Reflections on medicine, ethics, and euthanasia. Issues in Law \& Medicine 2010;26(1):33-76.

12. Biyoetik Terimleri Sözlüğü. Editör: Oğuz Y, Tepe H, Örnek Büken N, Kırımsoy Kucur D. 1. Basım Ankara: Türkiye Felsefe Kurumu Yayınları; 2005 pp:193-194.

13. Üstün Ç. Ötanazi istemli bir hak mı, cinayet mi? Tıp Etiği Kavramlarına Giriş. İzmir, Ege Üniversitesi Tıp Fakültesi Yayınları; 2002. pp:101-17

14. Karaaslan B ve ark. Hemşirelerin çalıştıkları bölümlere göre ötanazi hakkındaki görüşlerinin değerlendirilmesi. Dicle Tıp Dergisi 2014;41(4):700-6.

15. Çalışkan D, Özdemir O, Akdur R. Abidinpaşa sağlık grup başkanlığı bölgesinde çalışan hekimlerin ötanazi konusunda bilgi tutum davranışları ile ilgili bir çalışma. T Klinikleri Tıp Etiği-Hukuku-Tarihi Dergisi 2003;11:91-101.

16. Beder A ve ark. Hemşire ve hekimlerin ötanaziye ilişkin görüşleri. Klinik ve Deneysel Araştırmalar Dergisi 2010;1(2):91-8.

17. Tepehan S, Özkara E, Yavuz MF. Yoğun bakım ve diğer birimlerde görev yapan hemşirelerin ötanaziye yaklaşımı. Adli Tıp Dergisi 2011;25(2):115-24

18. Kavas MV ve ark. Ankara üniversitesi tıp fakültesi öğrencilerinde ölüm ve ölümcül hastadan kaçınıcı tutum düzeyleri. Ankara Üniversitesi Tıp Fakültesi Mecmuası 2012; 65(1):19-32.

19. Şenol S, ve ark. Hekimler için ötanazi, ölüm ve ölümcül hastaya ilişkin tutum ölçeği'nin faktör yapısı ve iç tutarlığı. 3P Dergisi 1996;4(3):185-190.

20. Engin E ve ark. Tıp ve hemşirelik fakültesi öğrencilerinin ötanaziye karşı tutumları. Uluslararası Sosyal Araştırmalar Dergisi 2017;10(52):654-59.

21. İnci F. Hemşirelerin Uygulanan Ölüme İlişkin Eğitimin Hemşirelerin Kaygı, Depresyon ve Tutumlarına Etkisi. Tez Danışmanı Prof. Dr. Fatma Öz. Hacettepe Üniversitesi Sağlık Bilimleri Enstitüsü Psikiyatri Hemşireliği Programı Doktora Tezi. Ankara: 2008.

22. Demir G, Biçer S, Ünsal A. Hemşirelik öğrencilerinin ötanaziye ilişkin düşünceleri. Gümüşhane Üniversitesi Sağlık Bilimleri Dergisi 2016;5(1):1-11.

23. Kumaş G. Adana İlindeki Çeşitli Hastanelerin yoğun bakım ünitelerinde çalışan hemşirelerin ötanazi hakkındaki düşünceleri. Tez Danışmanı: Prof Dr Nazan Alparslan. Çukurova Üniversitesi Sağlık Bilimleri Enstitüsü Hemşirelik Anabilim Dalı Yüksek Lisans Tezi. Adana: 2005.

24. Alborzi J, et al. Investigating of moral distress and attitude to euthanasia in the intensive care unit nurses. Int $\mathrm{J}$ Pediatr 2018;6(11):8475-82.

25. Ray R, Raju M. Attitude towards euthanasia among ethiopian health professionals and its relationship with their death anxiety. International Journal of Multidisciplinary Educational Research 2017;6(9):157-72.

26. Özkıriş $A$, ve ark. Hekim tutumları üzerine bir çalışma: ölüm ve ölümcül hastaya yaklaşım. Düşünen Adam Psikiyatri ve Nörolojik Bilimler Dergisi 2011;24:89-100.

27. Uysal C, ve ark. Hekimlerin ölümle karşılaşma sıklıklarına göre ötanazi hakkındaki görüşlerinin değerlendirilmesi. Adli Tıp Bülteni 2013;18(3):91-7.

28. Kara B, Günay O. Euthanasia-related knowledge and attitudes of Intensive care nurses working in five provinces in central anatolian region. Yoğun Bakım Dergisi 2017;8(3):77-81.

29. Özdemir K. Yoğun bakım hemşirelerinde görülen ölüm kaygısı. Tez Danışmanı: Yard Doç Dr Mine Ekinci. Atatürk Üniversitesi Sağlık Bilimleri Enstitüsü Psikiyatri Hemşireliği Anabilim Dalı Yüksek Lisans Tezi. Erzurum: 2014.

30. Nehir S, ve ark. Üniversite öğrencilerinin ötenaziye ilişkin düşünceleri: bir yüksekokul örneği. Fırat Sağlık Hizmetleri Dergisi 2006;1(2):26-36.

31. Iranmanesh S, Dargahi H, Abbaszadeh A. Attitudes of Iranian nurses toward caring for dying patients. Palliative and Supportive Care 2008;6:363-9.

32. Kumral B, Özdeş T. Tekirdağ ilindeki hekimlerin ötenaziye yaklaşımlarının değerlendirilmesi. Int J Basic Clin Med 2013;1(3):150-6.

33. Çelik S, ve ark. Yoğun bakım hemşirelerinin ötenazi hakkındaki düşünceleri. DEUHYO ED 2012;5(3):101-109.

34. Akkurt Yalçıntürk A, Batmaz M. Sağlık profesyonellerinin ötanazi hakkındaki düşünceleri. Hemşirelik Bilimi Dergisi 2018;1(2):2328.

35. Çelik N. Yoğun bakım hemşirelerinin ölüme ve saygın ölüm ilkelerine ilişkin tutumları. Mersin Üniv Saglık Bilim Dergisi 2019;12(2):316-27. 